\title{
Schizofreni - hva viser strukturell MR?
}

\begin{abstract}
BAKGRUNN Schizofreni er en alvorlig psykisk sykdom som rammer flere av hjernens funksjoner. MR-teknikken har muliggjort in vivo-studier av hjerneanatomi hos pasienter med schizofreni med mål om å forstå mer av sykdommen.
\end{abstract}

KUNNSKAPSGRUNNLAG Artikkelen bygger på et søk i PubMed på «schizophrenia MRI» samt egen forskning og erfaring. Vi inkluderte studier som omhandler strukturell MR, var utført på mennesker, skrevet på engelsk. Her presenterer vi et utvalg som vi mener er representativt for feltet.

RESULTATER Ved schizofreni ses mindre totalt hjernevolum og større ventrikler. Spesifikke subkortikale regioner er affisert, med volumreduksjon i hippocampus og thalamus, og volumøkning i globus pallidus. I cortex ses endrede foldingsmønstre samt redusert kortikalt volum og tykkelse, mest uttalt i frontal- og temporallappen. Funnene er på gruppenivå det er stor grad av overlapp mellom syke og friske, og effektstørrelsene er moderate til små. Flere av forandringene er til stede ved sykdomsdebut, noe som støtter at schizofreni kan være forårsaket av en forstyrrelse i nevroutviklingen. Det er rapportert anatomiske endringer over tid, men det er usikkert hva endringene representerer.

FORTOLKNING Forskningslitteraturen viser at schizofreni har nevroanatomiske korrelater som kan ses på gruppenivå ved å studere MR-bilder. Bruk av strukturell MR kan per i dag ikke benyttes til å identifisere schizofreni på individnivå.

Schizofreni er en alvorlig sykdom med en livstidsprevalens på ca. $1 \%$. Den underliggende patofysiologien er ukjent. Det finnes per i dag ingen «objektive» målbare kriterier for diagnostisering av schizofreni, men det er vanlig å inkludere radiologiske undersøkelser som computertomografi (CT) eller magnetisk resonans (MR) av hodet ved utredningen, primært for å utelukke cerebrale somatiske årsaker til psykosesymptomer og endret atferd. Men kan MR-skanning av pasienter med schizofreni si noe utover tilstedeværelse eller fravær av hjerneorganisk patologi? Kan stadig mer sofistikerte MR-postprosesseringsverktøy og høyere oppløsning på MR-bildene øke kunnskapen om de patofysiologiske prosessene som er knyttet til sykdommen? Kan man bruke MR-bilder til å skille mellom friske og syke?

De første in vivo-hjerneskanningene av pasienter med schizofreni ble foretatt med pneumoencefalografi (skanning av ventriklene) allerede i 1927 (1). Dette var en smertefull undersøkelse der luft ble injisert i cerebrospinalkanalen, og en av bivirkningene var hodepine som kunne vare i månedsvis (2). CT caput-undersøkelsene som ble tatt $\mathrm{i}$ bruk i schizofreniforskningen mot slutten av 1970årene var smertefrie, men medførte store stråledoser (3). MR-undersøkelsene vi bruker i dag er både smertefrie og uten strålebelastning eller andre bivirkninger. Dette har gjort det mulig i forskningsøyemed å undersøke store grupper av pasienter og friske kontrollpersoner med gjentatt MR-skanning. Antallet vitenskapelige studier der MR er blitt brukt for å undersøke anatomiske forandringer ved schizofreni, har økt betydelig de senere årene. Vi vil i det følgende gi en oversikt over denne litteraturen.

\section{Kunnskapsgrunnlag}

Artikkelen bygger på et søk i PubMed i juni 2012 med søkeordene «schizophrenia MRI» samt forfatternes (alle med ph.d.-grader som omhandler MR-forandringer ved schizofreni) egen forskning og erfaring. Litteratursøket resulterte i 4099 treff. Vi har valgt å avgrense denne artikkelen til å omhandle hjerneforandringer ved schizofreni vist ved bruk av strukturell MR, med andre ord vil vi beskrive og diskutere anatomiske, og ikke funksjonelle, forandringer. Gjennom denne avgrensningen vil vi kunne gi en grundigere oversikt over dette feltet, opprettholde ønsket presisjonsnivå og holde oss innenfor vår spisskompetanse. Det er dessuten strukturelle MR-bilder som rekvireres ved psykiatriske avdelinger i dag. Etter en systematisk gjennomgang har vi ekskludert artikler som ikke omtaler strukturell MR (2 783 artikler), ikke er skrevet på engelsk (203 artikler) og ikke inkluderer mennesker (278 artikler). Av de resterende 835 artiklene presenterer vi et subjektivt utvalg, basert på aktualitet, størrelse, metodologisk robusthet og vår kjennskap til dyktige og etablerte forskningsgrupper innen feltet. Vi har også inkludert noen av våre egne studier. For å begrense litteraturlisten omtaler vi flere gode metaanalyser og oversiktsartikler. Disse vil også være nyttige innfallsporter til videre fordypning i temaet.

\section{Unn Kristin Haukvik}

unn.haukvik@medisin.uio.no

K.G. Jebsen senter for psykoseforskning

Institutt for klinisk medisin

Universitetet i Oslo

og

Avdeling for psykiatrisk forskning

Diakonhjemmet Sykehus

Cecilie Bhandari Hartberg

Voksenpsykiatrisk avdeling

Diakonhjemmet sykehus

\section{Ingrid Agartz}

K.G. Jebsen senter for psykoseforskning Institutt for klinisk medisin Universitetet i Oslo

og

Avdeling for psykiatrisk forskning

Diakonhjemmet sykehus

Se også kunnskapsprøve

på www.tidsskriftet.no/quiz

ar Engelsk oversettelse på www.tidsskriftet.no > Se også side 822

\section{HOVEDBUDSKAP}

Pasienter med schizofreni har som gruppe forandringer i en rekke hjernestrukturer, inkludert cortex, hippocampus og ventriklene

MR-bilder av enkeltindivider kan ikke brukes til diagnostikk

MR-bilder kan øke forståelsen av patofysiologien ved schizofreni 


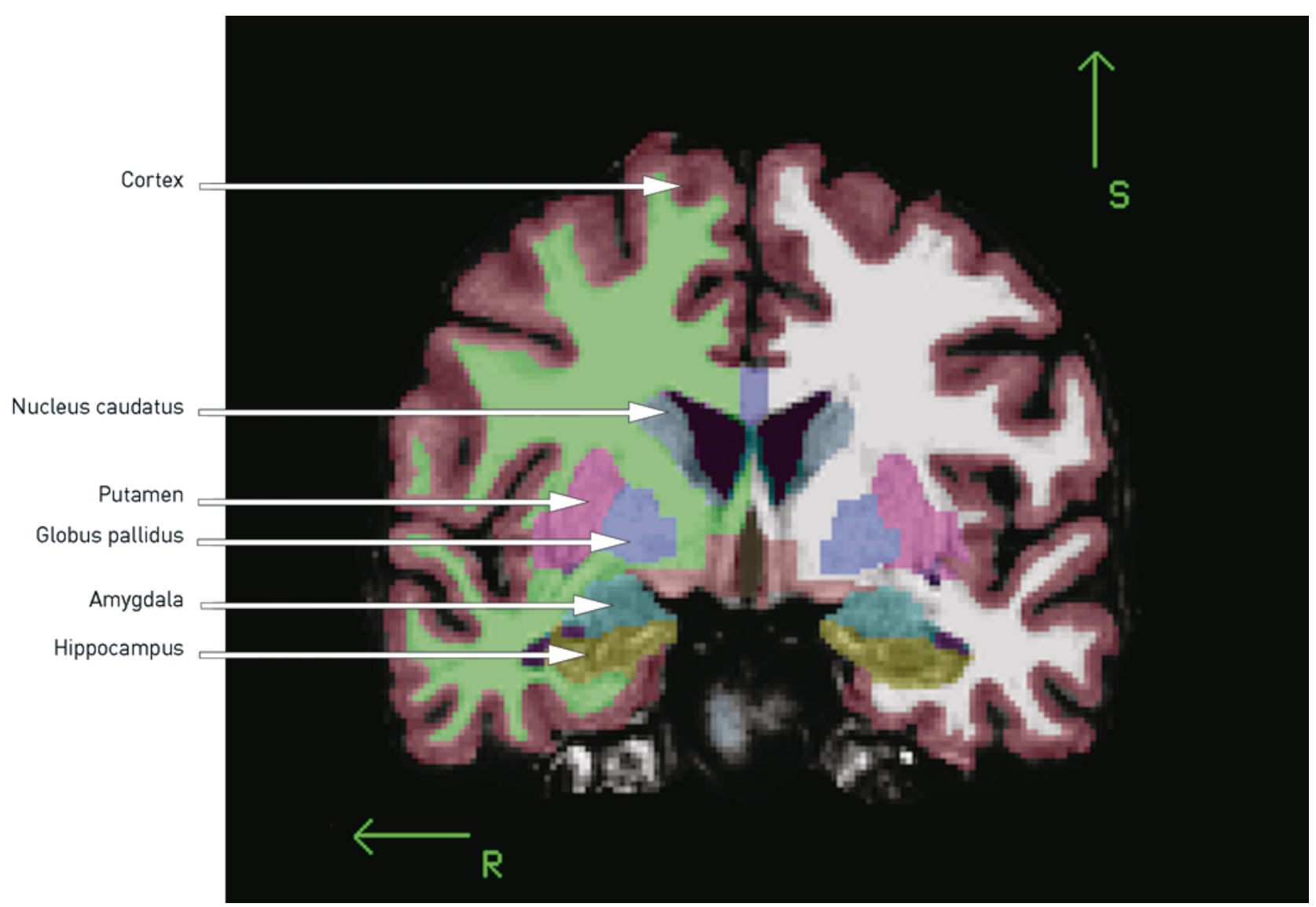

Figur 1 Koronalsnitt av T1-vektet MR-bilde, automatisk volumestimering med MR-postprosesseringsverktøyet FreeSurfer. $R=$ høyre, $S=$ superior

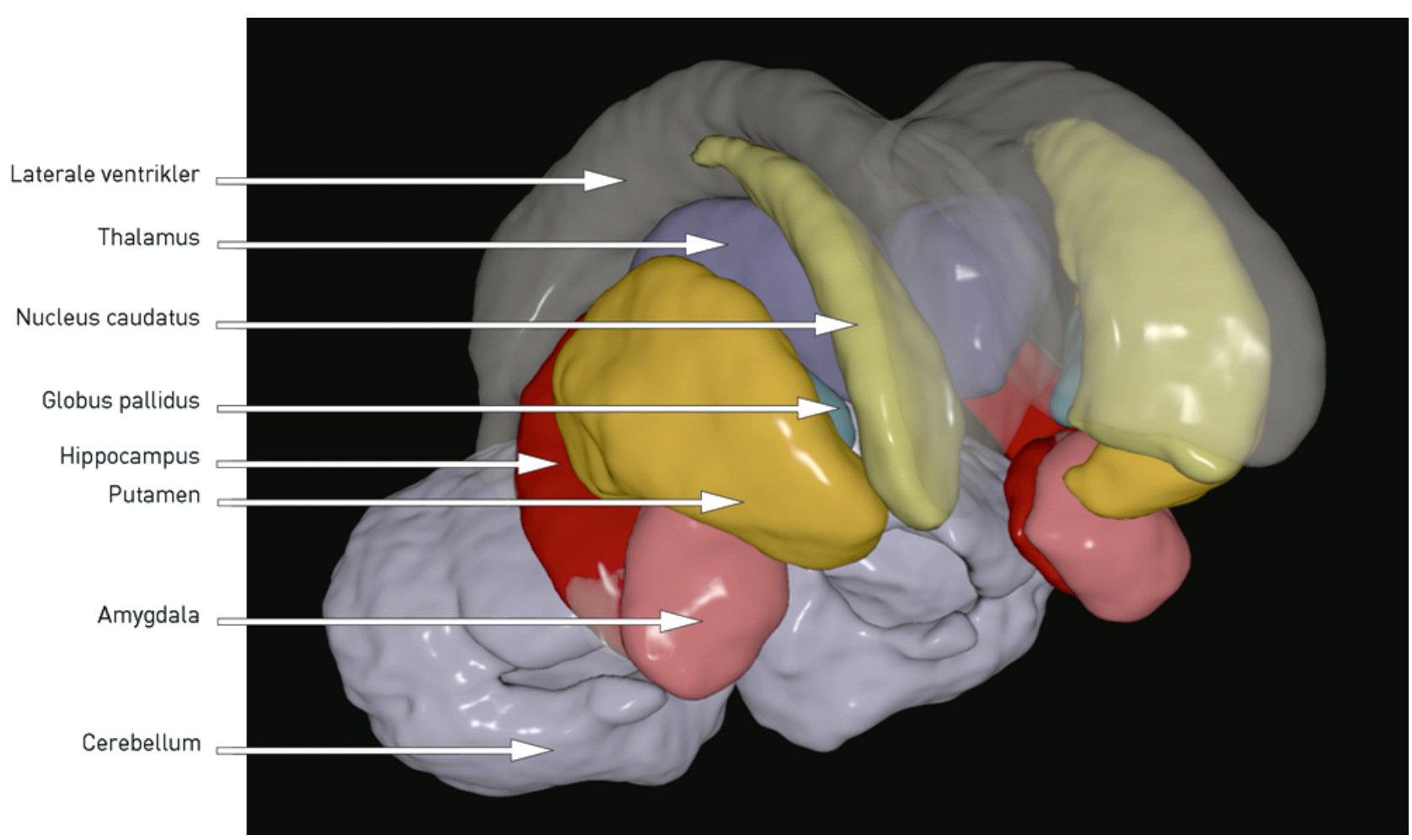

Figur 2 Tredimensjonal illustrasjon av subkortikale strukturer basert på et templat fra MR-postprosseseringsverktøyet FreeSurfer. Illustrasjon @ Ørjan Bergmann 


\section{Resultater}

Allerede pneumoencefalografien i 1920- og 30-årene og CT-forskningen i 1970- og 80årene viste at pasienter med schizofreni har større hjerneventrikler enn friske kontrollpersoner på gruppenivå, og senere MRforskning har bekreftet dette (4). Cohens d kan brukes som mål på effektstørrelse når man måler forskjeller mellom grupper. $\mathrm{d}<0,4$ anses som liten effekt, $\mathrm{d}=0,4-0,8$ som moderat og $d>0,8$ som stor effekt. Metaanalyser viser et moderat større sideventrikkelvolum ved kronisk schizofreni $(d=0,49$ (5)) og ved førsteepisode schizofreni $(\mathrm{d}=0,61$ (venstre) og 0,47 (høyre)) (6). I et norsk materiale fant vi et moderat større ventrikkelvolum $(\mathrm{d}=0,41$ (høyre) og $\mathrm{d}=0,38$ (venstre)) (7). En hypotese er at større ventrikkelvolum kan henge sammen med mindre volum av andre hjernestrukturer (8). Man kan tenke seg at når volum av grå og hvit substans er mindre, vil ventrikkelvolumet være større for å «fylle opp» intrakranialt volum.

Totalt hjernevolum er blitt brukt som et indirekte mål på strukturell integritet. Det er funnet mindre totalt hjernevolum hos pasienter med schizofreni sammenliknet med friske kontrollpersoner (9), men ved metaanalyse er effektstørrelsen liten $(d=-0,25)$ (5). Tilsvarende rapporterte man i en metaanalyse et mindre totalvolum (på 2,7\%) ved førsteepisode schizofreni sammenliknet med friske kontrollpersoner (10).

Når totalvolumet er mindre og ventriklene større, kan man spørre seg om det er visse regioner eller strukturer der volumreduksjonen er mer uttalt. Her følger en kort oversikt over de best replikerte funnene (for illustrasjon, se fig 1 og fig 2):

Hippocampus ligger medialt i temporallappen og er viktig for verbal innlæring og hukommelse. Denne er jevnt over rapportert å være mindre hos pasienter med schizofreni enn hos friske kontrollpersoner $(4,9)$, noe vi også har rapportert fra to skandinaviske kohorter $(7,11,12)$. I en nylig publisert metaanalyse av 44 MR-studier ble effektstørrelsen funnet å være moderat $(\mathrm{d}=-0,48$ og $-0,53$ for henholdsvis venstre og høyre hippocampus) (13), og det var ingen forskjell mellom førsteepisode og kronisk schizofreni. At forandringene var til stede ved sykdomsdebut, kan tyde på at hippocampusreduksjonen ved schizofreni er utviklingsrelatert. Volumreduksjonen kan representere tap av grå substans, og dette kan ha betydning for kognitive funksjoner som innlæring og hukommelse, som er vist nedsatt ved schizofreni (14).

Det er i flere studier, inkludert våre egne $(7,11,15)$, og i metaanalyser $(5,16,17)$ vist større volum av basalgangliene, spesielt uttalt i globus pallidus, ved schizofreni. Basalgangliene er dopaminfiberrike, og forandringer kan derfor være vanskelig å tolke siden strukturene påvirkes av antidopaminerge antipsykotika (18).
Thalamus, en midtlinjestruktur som grenser mot ventriklene, har vist seg å være mindre hos pasienter med schizofreni (19). I en metaanalyse er det vist effektstørrelse på $\mathrm{d}=-0,32$ (høyre) og $\mathrm{d}=-0,33$ (venstre) ved kronisk og $\mathrm{d}=-0,45$ (høyre) og $\mathrm{d}=-0,48$ (venstre) ved førsteepisode schizofreni (20). Thalamus fungerer som knutepunkt for hjernens kognitive prosesser, og en hypotese er at informasjonsflyten mellom ulike hjerneområder er forstyrret ved schizofreni (21).

Cortex er en innfløkt struktur med sulci og gyri. Nevronene i cortex er blant annet involvert i viljestyrte og kompliserte kognitive prosesser. De første MR-studiene påviste mindre volum av cortex, spesielt i frontal- og temporallappen (4). Volumreduksjonen er blitt replikert i flere senere studier og kan reflektere reduksjon av nevropil (umyeliniserte nerveceller, synapser og gliaceller), som vist ved nevropatologiske post mortemstudier (22). Mindre volum kan skyldes redusert tykkelse og/eller areal (volum $=$ tykkelse $\mathrm{x}$ areal). I vår gruppes studie fra Oslo fant vi tynnere cortex samt mindre areal og volum ved schizofreni, der volumforandringene var «drevet» av tykkelsesreduksjonen (23). Dette stemmer overens med flere andre studier som viser tynnere cortex, mest uttalt frontalt og temporalt, ved schizofreni (24-26).

Redusert kortikal folding (gyrifisering) ved schizofreni er funnet i flere studier, men det er også vist og replikert at ett område i høyre frontallapp har økt gyrifisering (27-30). Dette er spesielt interessant fordi cortex naturlig folder seg slik at områder som kommuniserer kommer nærmere hverandre (minker avstanden for nervesignalene) (31). Man vet også at gyrifiseringen foregår prenatalt (31), hvilket peker mot at endringene i kortikal folding representerer tidlig utviklingsavvik. Dette igjen støtter teorien om at schizofreni har en nevroutviklingsrelatert etiologi.

Hvorvidt hjerneanatomien ved schizofreni endrer seg over tid eller ikke, kan si noe om den underliggende patofysiologien. Det er vist longitudinelle endringer i kortikal tykkelse, men ikke areal, ved schizofreni (32), og man har funnet at reduksjon i kortikal tykkelse over tid korrelerer med sykdommens alvorlighetsgrad (33). Ved førsteepisode schizofreni er det vist longitudinelle reduksjoner i grå substans i frontallappen og thalamus samt i hvit substans frontalt, temporalt og parietalt. Endringene var tydeligst de første årene etter sykdomsdebut og samsvarte med redusert kognitiv funksjon, men ikke med andre symptomer (34). I en metaanalyse av 27 studier fant man longitudinelle forandringer i både grå og hvit substans (35). Det har vært foreslått at progressive endringer kan være knyttet til bruk av antipsykotika eller kan representere degenerative prosesser, men dette er kontroversielt. Det er også noe usikkerhet om det er reelle longitudinelle forandringer eller om funnene representerer metodologiske svakheter.

\section{Diskusjon}

Innledningsvis stilte vi tre spørsmål rundt hva MR-bilder kan si om schizofreni. I det følgende vil vi med bakgrunn i den refererte litteraturen svare på disse.

\section{Vise mer enn hjerneorganisk patologi?}

Vårt første spørsmål var: Kan MR-skanning av pasienter med schizofreni si noe utover tilstedeværelse/fravær av hjerneorganisk patologi? Svaret er ja. Volum av mer eller mindre alle hjernestrukturer har i en eller flere studier blitt assosiert med schizofreni. Således kan det virke som pasienter med schizofreni har massive hjerneanatomiske forandringer, men dette er ikke tilfelle. Effektstørrelsene er moderate til små, og det er stor grad av overlapp mellom syke og friske. Likevel er det etablert at pasienter med schizofreni har tynnere cortex i visse deler av hjernen, de har større laterale ventrikler og mindre hippocampus - på gruppenivå - enn friske kontrollpersoner. Fra studier med datadrevne og avanserte statistiske metoder ser vi lovende resultater innen diagnostisk klassifikasjon $(36,37)$, men dette er foreløpig kun på forskningsstadiet.

\section{Vise mer med bedre teknologi?}

Innen vårt forskningsfelt er vi opptatt av det andre spørsmålet: Kan man ved hjelp av stadig mer sofistikerte MR-postprosesseringsverktøy og høyere oppløsning på MR-bildene øke kunnskapen om de patofysiologiske prosessene som er knyttet til sykdommen? At man i flere studier finner hjerneforandringer ved sykdomsstart, tyder på at schizofreni ikke er en nevrodegenerativ sykdom. Dette har man allerede sett i nevropatologiske studier ved at man ikke har funnet nevronal gliose ved schizofreni. Hvorvidt det også er progredierende forandringer i hjerneanatomi ved schizofreni - og hva de i så fall representerer - er ikke klarlagt (se ovenfor). De fleste kliniske studier har så langt vært gjort på 1,5-tesla-MRskannere, men 3T-skannere overtar nå i større grad. Dette gir bedre oppløsning. Høyere oppløsning på bildene gir mulighet for å oppdage mer subtile forskjeller mellom schizofrenipasienter og kontrollpersoner. Dataprogrammene vi bruker for å analysere bildene blir stadig mer avanserte. For eksempel finnes programmer som måler kortikal tykkelse, folding og areal i over 300000 punkter som til sammen dekker hele hjerneoverflaten. Man kan også segmentere hippocampus slik at man kan se de ulike subregionene. Dette økte presisjonsnivået kan gjøre det mulig å bruke MR-bilder til å forstå mer av de patofysiologiske prosessene ved schizofreni.

\section{Skille syk fra frisk?}

Til slutt vil vi svare på det tredje spørsmålet: Dersom forskjellene mellom pasienter og kontrollpersoner er så små og kun til stede på gruppenivå, kan vi da bruke MR-bilder til å 
skille mellom friske og syke? Basert på vår oversikt blir svaret til klinikerne nei. Schizofreni er en klinisk diagnose. Forskersvaret blir - ydmykt: Kanskje vi kan det en gang i fremtiden. Vi kan per i dag se trekk ved schizofreni på MR-bilder, men ikke på individnivå.

\section{Unn Kristin Haukvik (f. 1974)}

er ph.d. og lege i spesialisering i psykiatri ved Diakonhjemmet Sykehus. Hun er postdoktor ved Universitetet i Oslo og har forskeropphold ved University of California San Diego.

Forfatter har fylt ut ICMJE-skjemaet og oppgir ingen interessekonflikter.

\section{Cecilie Bhandari Hartberg (f. 1975)}

er ph.d. og lege i spesialisering i psykiatri ved Diakonhjemmet Sykehus.

Forfatter har fylt ut ICMJE-skjemaet og oppgir ingen interessekonflikter.

\section{Ingrid Agartz (f. 1953)}

er professor i psykiatri, overlege ved Avdeling for psykiatrisk forskning og undervisning ved Diakonhjemmet Sykehus og adjungerende professor ved Institutionen för klinisk neurovetenskap, Karolinska Institutet. Hun har over 20 års forskningserfaring fra MR- og schizofrenifeltet. Forfatter har fylt ut ICMJE-skjemaet og oppgir ingen interessekonflikter.

\section{Litteratur}

1. Jacobi W. Winkler H. Encephalogrpische studien an chronischen schizophrenen. Arch Psychiatr Nervenkr 1927; 81: 299-332.

2. Leeds NE, Kieffer SA. Evolution of diagnostic neuroradiology from 1904 to 1999. Radiology 2000; 217: $309-18$.

3. Johnstone EC, Crow TJ, Frith CD et al. Cerebral ventricular size and cognitive impairment in chronic schizophrenia. Lancet 1976; 2: 924-6.

4. Shenton ME Whitford TJ Kubicki M. Structural neuroimaging in schizophrenia: from methods to insights to treatments. Dialogues Clin Neurosci 2010; 12: 317-32.

5. Wright IC, Rabe-Hesketh S, Woodruff PW et al. Meta-analysis of regional brain volumes in schizophrenia. Am J Psychiatry 2000; 157: 16-25.

6. Vita A, De Peri L, Silenzi C et al. Brain morphology in first-episode schizophrenia: a meta-analysis of quantitative magnetic resonance imaging studies. Schizophr Res 2006: 82: 75-88

7. Rimol LM, Hartberg CB, Nesvåg R et al. Cortical thickness and subcortical volumes in schizophrenia and bipolar disorder. Biol Psychiatry 2010; 68: 41-50.

8. Horga G, Bernacer J, Dusi N et al. Correlations between ventricular enlargement and gray and white matter volumes of cortex, thalamus, striatum, and internal capsule in schizophrenia. Eur Arch Psychiatry Clin Neurosci 2011: 261: 467-76.

9. Shepherd AM, Laurens KR, Matheson SL et al. Systematic meta-review and quality assessment of the structural brain alterations in schizophrenia. Neurosci Biobehav Rev 2012; 36: 1342-56.

10. Steen RG, Mull C, McClure R et al. Brain volume in first-episode schizophrenia: systematic review and meta-analysis of magnetic resonance imaging studies. Br J Psychiatry 2006; 188: 510-8.

11. Hartberg CB, Sundet K, Rimol LM et al. Subcortical brain volumes relate to neurocognition in schizophrenia and bipolar disorder and healthy controls. Prog Neuropsychopharmacol Biol Psychiatry 2011; 35: 1122-30.

12. Haukvik UK, Saetre P, McNeil T et al. An exploratory model for $G \times$ E interaction on hippocampal volume in schizophrenia; obstetric complications and hypoxia-related genes. Prog Neuropsychopharmacol Biol Psychiatry 2010; 34: 1259-65.

13. Adriano F, Caltagirone C, Spalletta G. Hippocampal volume reduction in first-episode and chronic schizophrenia: a review and meta-analysis. Neuroscientist 2012; 18: 180-200.

14. Mesholam-Gately RI, Giuliano AJ, Goff KP et al. Neurocognition in first-episode schizophrenia: a meta-analytic review. Neuropsychology 2009; 23: $315-36$.

15. Haukvik UK, McNeil T, Nesvåg R et al. No effect of obstetric complications on basal ganglia volumes in schizophrenia. Prog Neuropsychopharmacol Biol Psychiatry 2010; 34: 619-23.

16. Ellison-Wright I, Bullmore E. Anatomy of bipola disorder and schizophrenia: a meta-analysis. Schizophr Res 2010; 117: 1-12.

17. Glahn DC, Laird AR, Ellison-Wright I et al. Metaanalysis of gray matter anomalies in schizophrenia: application of anatomic likelihood estimation and network analysis. Biol Psychiatry 2008; 64: 774-81.

18. Scherk H. Falkai P. Effects of antipsychotics on brain structure. Curr Opin Psychiatry 2006; 19: $145-50$.

19. Smith MJ, Wang L, Cronenwett W et al. Thalamic morphology in schizophrenia and schizoaffective disorder. J Psychiatr Res 2011; 45: 378-85.

20. Adriano F, Spoletini I, Caltagirone C et al. Updated meta-analyses reveal thalamus volume reduction in patients with first-episode and chronic schizophrenia. Schizophr Res 2010; 123: 1-14.

21. Andreasen NC, Paradiso S, O'Leary DS. «Cognitive dysmetria» as an integrative theory of schizophrenia: a dysfunction in cortical-subcortical-cerebellar circuitry? Schizophr Bull 1998; 24: 203-18.

22. Selemon LD, Rajkowska G, Goldman-Rakic PS. Abnormally high neuronal density in the schizophrenic cortex. A morphometric analysis of prefrontal area 9 and occipital area 17. Arch Gen Psychiatry 1995: 52: 805-18, discussion 819-20.

23. Rimol LM, Nesvåg R, Hagler DJ Jr et al. Cortical volume, surface area, and thickness in schizophrenia and bipolar disorder. Biol Psychiatry 2012 71: $552-60$.

24. Goldman AL, Pezawas L, Mattay VS et al. Widespread reductions of cortical thickness in schizophrenia and spectrum disorders and evidence of heritability. Arch Gen Psychiatry 2009; 66: 467-77.

25. Schultz CC, Koch K, Wagner G et al. Reduced cortical thickness in first episode schizophrenia. Schizophr Res 2010; 116: 204-9

26. Nesvåg R, Lawyer G, Varnäs K et al. Regional thinning of the cerebral cortex in schizophrenia: effects of diagnosis, age and antipsychotic medication. Schizophr Res 2008; 98: 16-28.

27. Falkai P, Honer WG, Kamer T et al. Disturbed frontal gyrification within families affected with schizophrenia. J Psychiatr Res 2007; 41: 805-13.

28. Cachia A, Paillère-Martinot ML, Galinowski A et al. Cortical folding abnormalities in schizophrenia patients with resistant auditory hallucinations Neuroimage 2008; 39: 927-35

29. Harris JM Moorhead TW Miller P et al Increased prefrontal gyrification in a large high-risk cohort characterizes those who develop schizophrenia and reflects abnormal prefrontal development. Biol Psychiatry 2007; 62: 722-9.

30. White T, Hilgetag CC. Gyrification and neural connectivity in schizophrenia. Dev Psychopathol 2011 23: $339-52$
31. White T, Su S, Schmidt M et al. The development of gyrification in childhood and adolescence. Brain Cogn 2010; 72: 36-45.

32. Cobia DJ, Smith MJ, Wang L et al. Longitudinal progression of frontal and temporal lobe changes in schizophrenia. Schizophr Res 2012; 139: 1-6.

33. van Haren NE, Schnack HG, Cahn W et al. Changes in cortical thickness during the course of illness in schizophrenia. Arch Gen Psychiatry 2011; 68: 871-80.

34. Andreasen NC, Nopoulos P, Magnotta V et al. Progressive brain change in schizophrenia: a prospective longitudinal study of first-episode schizophrenia. Biol Psychiatry 2011: 70: 672-9.

35. Olabi B, Ellison-Wright I, Mclntosh AM et al. Are there progressive brain changes in schizophrenia? A meta-analysis of structural magnetic resonance imaging studies. Biol Psychiatry 2011; 70: 88-96.

36. Orrù G. Pettersson-Yeo W, Marquand AF et al. Using Support Vector Machine to identify imaging biomarkers of neurological and psychiatric disease: a critical review. Neurosci Biobehav Rev 2012: 36: $1140-52$.

37. Sun D, van Erp TG, Thompson PM et al. Elucidating a magnetic resonance imaging-based neuroanatomic biomarker for psychosis: classification analysis using probabilistic brain atlas and machine learning algorithms. Biol Psychiatry 2009; 66 : 1055-60.

Mottatt 20.9. 2012, første revisjon innsendt 16.1. 2013, godkjent 27.2. 2013. Medisinsk redaktør Trine B. Haugen. 